\title{
The population density effects on the reproductive biology of the snail Bradybaena similaris (Férussac, 1821) (Mollusca, Gastropoda)
}

\author{
de Oliveira, CS. ${ }^{\text {a }}$ Vasconcellos, $M C .^{\text {b }}$ and Pinheiro, J. ${ }^{\text {a* }}$ \\ aÀrea de Biofísica, Departamento de Ciências Fisiológicas, Instituto de Biologia - IB, \\ Universidade Federal Rural do Rio de Janeiro - UFRRJ, \\ BR 465, Km 7, CEP 23890-000, Seropédica, RJ, Brazil \\ ${ }^{b}$ Fundação Instituto Oswaldo Cruz - FIOCRUZ, Instituto Oswaldo Cruz - IOC, \\ Av. Brasil, 4365, CEP 21040-900, Rio de Janeiro, RJ, Brazil \\ *e-mail:.jps@ufrrj.br \\ Received February 14, 2006 - Accepted July 21, 2007 - Distributed May 31, 2008 \\ (With 3 figures)
}

\begin{abstract}
The influence of population density on some aspects of the reproductive biology of the snail Bradybaena similaris was studied. Molluscs were maintained under 0.2 (isolated), 0.3, 0.6, 1.0, 1.3 and $1.7 \mathrm{snail} / \mathrm{m}^{2}$ densities. The animals maintained under 0.3 and 0.6 snail $/ \mathrm{m}^{2}$ showed the lowest numbers of eggs laid/snail, being the highest value observed to the 1.7 snail $/ \mathrm{m}^{2}$. The hatching of the snails maintained under 0.3 snail $/ \mathrm{m}^{2}$ density, begun at the $21^{\text {st }}$ day after laying, and the maximum time required to the hatching was 36 days was observed to the eggs came from snails maintained under the densities $0.6,1.0,1.3$ snail $/ \mathrm{m}^{2}$, respectively. The highest percentage hatchability $(55.56 \%)$ was observed to isolated snails. The galactogen content in the albumen gland did not seem to accompany the alterations occurred in the reproduction of $B$. similaris in response to the different population densities.
\end{abstract}

Keywords: reproductive biology, Bradybaena similaris, galactogen.

\section{Efeitos da densidade populacional na biologia reprodutiva do molusco Bradybaena similaris (Molusca, Gastropoda)}

\begin{abstract}
Resumo
A influência da densidade populacional em alguns aspectos da biologia reprodutiva do molusco Bradybaena similaris foi estudada. Os moluscos foram mantidos em densidades de 0.2 (isolados), 0.3, 0.6, 1.0,1.3 e $1.7 \mathrm{moluscos} / \mathrm{m}^{2}$. Nas densidades de 0.3 e 0.6 moluscos $/ \mathrm{m}^{2}$, os moluscos apresentaram os menores números de ovos postos por molusco, sendo o maior valor observado para essa variável na densidade de $1.7 \mathrm{molusco} / \mathrm{m}^{2}$. A eclosão dos moluscos mantidos a uma densidade de 0.3 molusco $/ \mathrm{m}^{2}$, iniciou-se aos 21 dias após a postura, sendo o tempo máximo necessário para a eclosão 36 dias para ovos oriundos de moluscos mantidos nas densidades de $0.6,1.0,1.3$ moluscos $/ \mathrm{m}^{2}$. O maior percentual de eclosão $(55.56 \%)$ foi observado para os moluscos isolados. O conteúdo de galactogênio na glândula de albúmem parece não acompanhar as alterações na reprodução de B. similaris em resposta a diferentes densidades populacionais.
\end{abstract}

Palavras-chave: biologia reprodutiva, Bradybaena similaris, galactogênio.

\section{Introduction}

The snail Bradybaena similaris (Férussac, 1821) is a land snail widely distributed throughout the Brazilian territory, being found in the tropical regions, according to Araújo (1989), and occupying mainly gardens. It also acts as an intermediate host in the life cycle of parasites, such as Eurytrema coelomaticum (Giard et Billet, 1892) Looss, 1907 (Mattos, 1987), Postharmostomum gallinum Witenberg, 1923 (Amato and Bezerra 1989), and Angiostrongylus costaricensis (Morera and Céspedes, 1971) (Thiengo 1995), acquiring medical, economic, veterinary and zoonotic importance. It is also an important plague to the different plant cultures with economic interest.
The laboratory breeding of $B$. similaris is an important aspect that must be well understood in order to allow the fulfilment of studies on the host-parasite relationship and also to develop efficient control methods. Some aspects related to the growth and reproduction of the biology of B. similaris were studied by Leahy (1984). The relationship between snail size and the reproductive activity are closely related, given that the egg production is influenced by the shell diameter.

The synthesis of the galactogen by the albumen gland is influenced by environmental conditions (Pinheiro and Amato 1994; Pinheiro 1996; Azevedo et al. 1996). According to Dan and Bailey (1982), population density 
has a negative effect on the growth and the reproduction of some species of snails, causing the delay of growth and low fecundity in Helix aspersa Müller, 1774.

In the present study, some aspects of the reproductive biology of $B$. similaris maintained under different population densities were analyzed, focusing on the oviposition, hatchability and galactogen content in these snails.

\section{Materials and Methods}

Specimens of $B$. similaris were collected from gardens located at Km 9, BR465, Seropédica, RJ, Brazil, and were maintained under laboratory conditions using glass vivaria prepared according to Leahy (1984) (room temperature $24 \pm 4{ }^{\circ} \mathrm{C}$ and relative humidity $70.5 \pm 13.5 \%$ ). The snails were distributed in glass vivaria in order to obtain the following densities: 0.2 (isolated snails), 0.3 (five snails), 0.6 (ten snails), 1.0 (fifteen snails), 1.3 (twenty snails) and 1.7 (twenty five snails) snail $/ \mathrm{m}^{2}$ and with two repetitions carried out on each group, except for the isolated snails, to which ten repetitions were used.

The snails were fed ad libidum with fresh lettuce leaves and the earth was moistened twice a week, using tap water. Daily, the earth of each vivaria was gently revolved to look for the eggs of $B$. similaris and the eggs found were collected, counted and transferred to another vivarium with an area of $5 \mathrm{~m}^{2}$. The number of dead snails was observed on alternate days.

After six weeks of observations, snails were dissected to remove the albumen gland tissue. The galactogen was extracted according to Pinheiro and Gomes (1994) and determined by the 3,5 DNS technique (Sumner, 1924). To evaluate the presence of another reducing sugar in the galactogen extracts paper chromatography of the extracted polysaccharide from the albumen gland was made, according to the routine technique (Villela et al., 1973).

The eggs laid by the snails maintained under different population densities were observed during one month, three times a week to verify the hatching of the snails.

The results obtained were expressed as mean \pm standard deviation. The Tukey test was used to compare means $(\alpha=5 \%)$ and the polynomial regression was employed to verify the relation between the parameters analyzed and the different population densities.

\section{Results}

The molluscs maintained under 0.3 and 0.6 snail/ $\mathrm{m}^{2}$ densities presented the lowest values for the number of eggs laid (Table 1). The density of 1.7 snail $/ \mathrm{m}^{2}$ resulted in the highest number of eggs laid by $B$. similaris. These lowest values represented a marked reduction of 72.70 and $74.65 \%$, respectively. The only value significatively different from the others was that observed for the snails maintained under the density of $1.7 \mathrm{snail} / \mathrm{m}^{2}$. The regression analysis test showed a strong positive relation between the population density and the mean number of eggs laid by B. similaris (Figure 1).
The oviposition rhythm showed an increase in the number of eggs laid while the population density was increased (Table 2). It was also observed that the ovipository activity begins earlier in the groups maintained under higher densities ( $0.6 \mathrm{snail} / \mathrm{m}^{2}$ onwards). The mean number of eggs laid/week was significantly higher in the snails maintained under 1.7 snail $/ \mathrm{m}^{2}$ density. A strong positive relation between the mean number of eggs laid/week and the population density was observed (Figure 2).

The minimum time required for hatching was 21 days, in the case of the snails that came from eggs laid by molluscs maintained under 0.3 snail $/ \mathrm{m}^{2}$, and the maximum hatching time of 36 days was exhibited by the snails of groups maintained under 0.6, 1.0 and $1.3 \mathrm{snail} / \mathrm{m}^{2}$. Although the snails from the group under 1.7 snails $/ \mathrm{m}^{2}$ showed the highest mean number of eggs laid/snail and eggs laid/week, the eggs laid by these snails did not present a high percentual hatchability. While the number of eggs laid per isolated snails was always among the lowest values observed, still the eggs laid by these snails presented the highest hatchability value (Table 3 ).

Table 1. Total and mean numbers of eggs laid by Bradybaena similaris maintained under different population densities, expressed as number of snails $/ \mathrm{m}^{2} . \mathrm{X} \pm \mathrm{SD}=$ mean \pm standard deviation. ${ }^{\mathrm{a}, \mathrm{b}, \mathrm{c}}=$ Different letters indicate significant difference between mean values $(\alpha=5 \%)$.

\begin{tabular}{ccc}
\hline $\begin{array}{c}\text { Population } \\
\text { densities } \\
\left.\text { (snails/m } \mathbf{m}^{2}\right)\end{array}$ & $\begin{array}{c}\text { Total number } \\
\text { of eggs }\end{array}$ & $\begin{array}{c}\text { Mean number of } \\
\text { eggs/snail } \\
\mathbf{X} \pm \text { SD }\end{array}$ \\
\hline 0.2 & 36 & $0.8 \pm 1.3^{\alpha}$ \\
0.3 & 24 & $0.5 \pm 0.8^{\mathrm{a}}$ \\
0.6 & 53 & $0.5 \pm 0.5^{\mathrm{a}}$ \\
1.0 & 167 & $1.0 \pm 1.1^{\mathrm{a}}$ \\
1.3 & 319 & $1.4 \pm 1.2^{\mathrm{a}, \mathrm{c}}$ \\
1.7 & 528 & $1.8 \pm 1.1^{\mathrm{b}, \mathrm{c}}$ \\
\hline
\end{tabular}

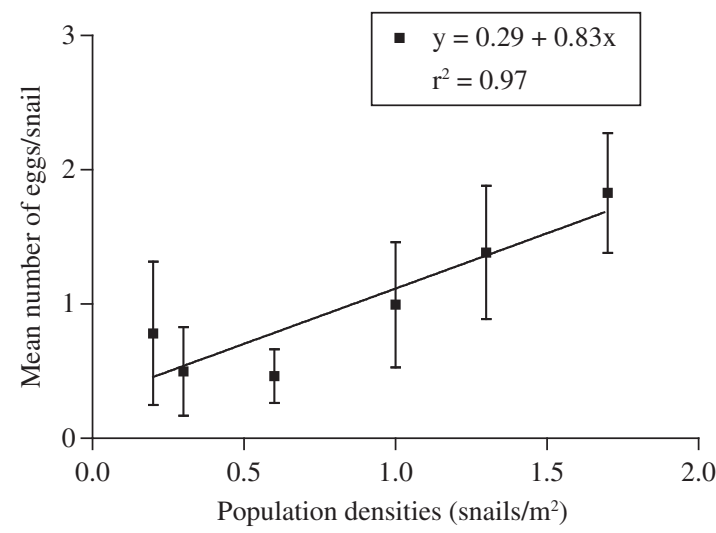

Figure 1. Relation between the mean number of eggs laid by Bradybaena similaris and the different population densities, expressed as number of snail $/ \mathrm{m}^{2}$. 
The galactogen content in the albumen gland of B. similaris did not show higher variation between the different population densities (Table 4). The maximum galactogen content was $63.303 \mathrm{mg}$ of galactose/g of tissue, wet weight, being this value observed in the snails maintained under $1.3 \mathrm{snail} / \mathrm{m}^{2}$ density. The lowest galac- togen content $(20.743 \mathrm{mg}$ of galactose/g of tissue, wet weight) was observed for the isolated snails, this value being significant and lower than that observed in the other groups. The polynomial regression test did not show a clear relation between the galactogen content and the different population densities (Figure 3).

Table 2. The oviposition rhythm of Bradybaena similaris, expressed as number of eggs laid/week, maintained under different population densities, expressed as number of snails $/ \mathrm{m}^{2} . \mathrm{X} \pm \mathrm{SD}=$ mean \pm standard deviation. ${ }^{\mathrm{a}, \mathrm{b}, \mathrm{c}, \mathrm{d}}=$ Different letters indicate significant difference between mean values $(\alpha=5 \%)$.

\begin{tabular}{|c|c|c|c|c|c|c|c|}
\hline \multirow[t]{2}{*}{ Population density $\left(\mathrm{snail} / \mathrm{m}^{2}\right)$} & \multicolumn{7}{|c|}{ Number of eggs laid/week } \\
\hline & $1^{\mathrm{a}}$ & $2^{a}$ & $3^{\mathrm{a}}$ & $4^{a}$ & $5^{a}$ & $6^{\mathrm{a}}$ & $\mathbf{X} \pm \mathbf{S D}$ \\
\hline 0.2 & 0 & 0 & 0 & 25 & 11 & 0 & $6.0 \pm 10.3^{\mathrm{a}}$ \\
\hline 0.3 & 0 & 0 & 0 & 0 & 15 & 9 & $4.0 \pm 6.5^{\mathrm{a}, \mathrm{c}}$ \\
\hline 0.6 & 0 & 11 & 25 & 11 & 6 & 0 & $8.8 \pm 9.3^{\mathrm{a}, \mathrm{c}}$ \\
\hline 1.0 & 0 & 20 & 38 & 86 & 23 & 23 & $27.8 \pm 32.0^{\mathrm{a}, \mathrm{c}}$ \\
\hline 1.3 & 0 & 59 & 58 & 131 & 12 & 59 & $53.2 \pm 46.2^{\mathrm{c}, \mathrm{c}}$ \\
\hline 1.7 & 24 & 102 & 109 & 162 & 101 & 30 & $88.0 \pm 52.4^{\mathrm{b}, \mathrm{c}}$ \\
\hline
\end{tabular}

Table 3. The beginning of hatching and hatchability rate of the eggs laid by Bradybaena similaris maintained under different population densities, expressed as number of snails $/ \mathrm{m}^{2}$.

\begin{tabular}{ccc}
\hline $\begin{array}{c}\text { Population } \\
\text { densities } \\
\left(\mathbf{s n a i l} / \mathbf{m}^{2}\right)\end{array}$ & $\begin{array}{c}\text { Beginning of } \\
\text { hatching } \\
\text { (days) }\end{array}$ & $\begin{array}{c}\text { Hatching rate } \\
(\%)\end{array}$ \\
\hline 0.2 & 31 & 55.6 \\
0.3 & 21 & 41.7 \\
0.6 & 36 & 41.5 \\
1.0 & 36 & 7.0 \\
1.3 & 36 & 31.7 \\
1.7 & 28 & 30.1 \\
\hline
\end{tabular}

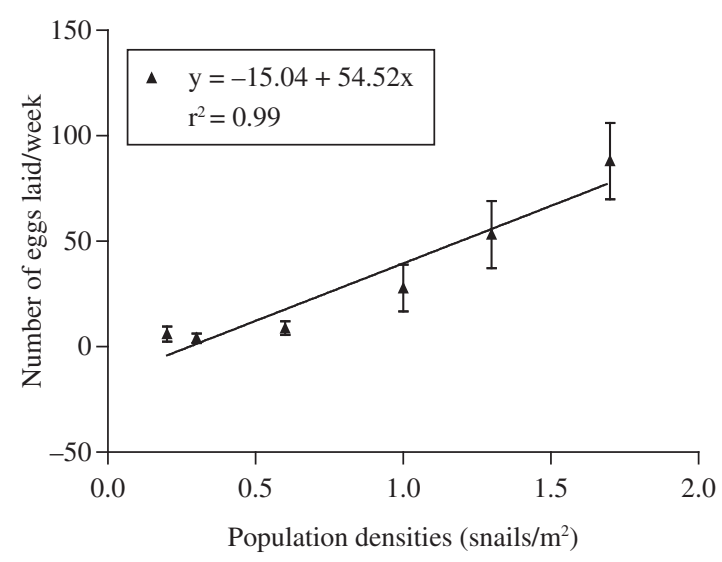

Figure 2. Relation between the number of eggs laid by Bradybaena similaris per week, through a period of six weeks, maintained under different population densities, expressed as number of snails $/ \mathrm{m}^{2}$.
Table 4. Galactogen content in the albumen gland of Bradybaena similaris, expressed as mg of galactose/g of tissue, wet weight, maintained under different population densities. $X$ $\pm \mathrm{SD}=$ mean \pm standard deviation. ${ }^{\text {ab, }, \mathrm{c}, \mathrm{d}}=$ Different letters indicate significant difference between mean values $(\alpha=5 \%)$.

\begin{tabular}{cc}
\hline $\begin{array}{c}\text { Population } \\
\text { densities } \\
\left(\mathbf{s n a i l} / \mathbf{m}^{2}\right)\end{array}$ & $\begin{array}{c}\text { Concentration of galactogen } \\
(\mathbf{m g} \text { of galactose/g of tissue, } \\
\text { wet weight }) \mathbf{X} \pm \mathbf{S D}\end{array}$ \\
\hline 0.2 & $20.7 \pm 5.3^{\mathrm{a}}$ \\
0.3 & $56.4 \pm 0.7^{\mathrm{c}, \mathrm{d}}$ \\
0.6 & $50.0 \pm 16.6^{\mathrm{d}}$ \\
1.0 & $36.9 \pm 1.9^{\mathrm{d}}$ \\
1.3 & $63.3 \pm 3.2^{\mathrm{b}, \mathrm{d}}$ \\
1.7 & $43.5 \pm 0.9^{\mathrm{d}}$ \\
\hline
\end{tabular}

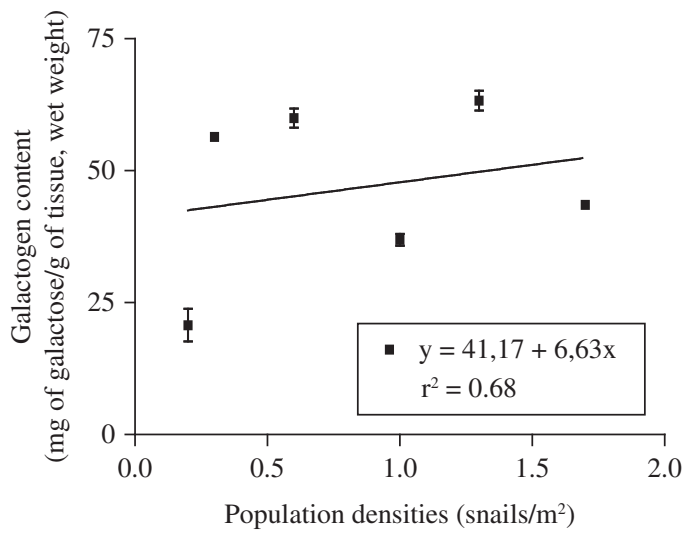

Figure 3. Relation between the galactogen content, expressed as $\mathrm{mg}$ of galactose/g of tissue, wet weight, in the albumen gland of Bradybaena similaris maintained under different population densities. 


\section{Discussion}

Almeida and Bessa (2000) analyzed the effects of the population density (10, 20, 30, 40 and 50 snail/box $)$ on the growth and reproduction of $B$. similaris and Leptinaria unilamellata (D’Orbigny, 1835) (Mollusca, Subulinidae). They showed a higher growth of the shell of $B$. similaris maintained under 10 snail/box, but the shell diameter is shown only at the end of the period of observation (180 days), so the values did not reflect the real growth of the snails once the initial size of the molluscs is not mentioned by the authors. The same authors showed that the mean number of eggs laid/snail was higher in the population density of 10 snail/box, but they did not relate the number of snails per area of the vivaria used in snails rearing.

In the present study a higher oviposition value was observed in snails maintained under 1.7 snail $/ \mathrm{m}^{2}$, where 25 specimens were reared in a vivaria, thus opposing the results presented by Almeida and Bessa (2000) and furthermore showing a positive relation between the population density and the number of eggs laid per B. similaris.

The oviposition rhythm of $B$. similaris during the six weeks of analysis, demonstrated that the egg number laid for $B$. similaris was higher for population density of 1.7 snails $/ \mathrm{m}^{2}$, indicating that the number of eggs laid/ week was higher for this density than in the other. Also, it was shown that the snails maintained under higher densities began the oviposition earlier than those maintained under lower densities. Almeida and Bessa (2001) showed no difference in the start of the oviposition for isolated and grouped B. similaris, but the isolated snails had the major intervals of ovipositions and the higher number of eggs laid/snail was observed in grouped snails. These results corroborate the observations of the present study.

This study showed the relation between fertility of B. similaris and population density. The observation of a higher viability, expressed as percentual hatching of the snails, in isolated molluscs must be a result of an ecological strategy, showing a pattern of survival strategy of these animals when isolated. The mean time of hatching is near to that observed by Almeida and Bessa (2000), who observed that the minimum time for eclosion was 14 days and the maximum time was 35 days with an average time of 23.69 days. Oliveira et al. (1971), recorded that the hatching occurred between 11 and 27 days, while Santos (1994) and Thomé et al. (1996), cited hatching occurrence between 18 and 25 days. For other species of terrestrial snails as Helix pomatia Linnaeus, 1758, a period of incubation between 17 and 30 days was needed (Vincent et al. 1982).

The percentual hatchability observed in the present study was always lower than the values cited by other authors. Leahy (1984) found mean hatchability of $77.5 \%$. Almeida and Bessa (2001) recorded percentual hatchability of $81.22 \%$.

Many studies, on different species of molluscs, demonstrated that the polysaccharide extracted from the albumen gland is an heteropolymer. Azevedo et al. (1996), through a chromatographic study, showed that the galactogen of the albumen gland of B. similaris is an homopolymer and that there are no other reducing sugars present in the extracted material according the technique of Pinheiro and Gomes (1994).

Van Elk and Joosse (1981) recorded the influence of the photoperiod, the starvation and the infection with larval trematodes on the catalytic activity of the enzyme UDP-galactose 4-epimerase in the albumen gland of Lymnaea stagnalis Linnaeus, 1758. However, this is the first time that the galactogen content is used to evaluate the reproductive biology of $B$. similaris kept under different population densities. It seems that there was no clear relation between the galactogen content in the albumen gland and the oviposition or viability of the eggs for B. similaris.

\section{References}

ALMEIDA, MN. and BESSA, ECA., 2000. Efeito da densidade populacional sobre o crescimento e a repordução de Bradybaena similaris (Férussac, 1821) (Mollusca, Xanthonychidae) e Leptinaria unilamellata (d'Orbigny, 1835) (Mollusca, Subulinae). Revta. Bras. Zooc., vol. 2, no. 1, p. 97-104.

-, 2001. Estudo do crescimento e da reprodução de Bradybaena similaris (Férussac, 1821) (Mollusca, Xanthonychidae) em laboratório. Revta. Brás. Zool., vol. 18, no. 4, p. 115-1122.

AMATO, SB and BEZERRA, JCB., 1989. Parasitismo natural de Bradybaena similaris (Férussac, 1821) por Postharmostomum gallinum Witenberg, 1923. Mem. Inst. Oswaldo Cruz, vol. 84, no. 1, p. $75-79$.

AZEVEDO, VPB., PINHEIRO. J., GOMES, EM., and CHAGAS, GM., 1996. Determinação do conteúdo de galctogênio na glândula de albúmen de Bradybaena similaris (Férussac, 1821) (Mollusca, Gastropoda). Revta. Univ. Rural série Ciências da Vida, vol. 18, no. 1-2, p. 95-99.

ARAÚJO, JLB., 1989. Moluscos de importância econômica na Brasil. I. Xanthonychidae: Bradybaena similaris (Férussac, 1821) (Mollusca, Gstropoda, Pulmonata, Stylommatophora). Revta. Bras. Zool., vol. 6, no. 4, p. 538-592.

DAN, N., and BAILEY, SER., 1982. Growth, mortality, and feeding rates of the snail Helix aspersa at different population densities in the laboratory, and the depression of activity of helicid snails by other individuals, or their mucus. J. Mollus. Stud., vol. 48, p. 257-265.

LEAHY, WM., 1984. Comportamento e características anatofuncionais da reprodução em Bradybaena similaris (Mollusca, Pulmonata). Ci. Cult. São Paulo, vol. 36, no. 8, p. 1389-1392.

MATTOS JR, DG., 1987. Eurytrema coelomaticum (Giard et Billet, 1982) Looss, 1907. Alguns aspectos do seu relacionamento com os hospedeiros intermediários e definitivo sob condições experimentais. UFRRJ. Itaguaí, RJ, Brasil. 87p. [Tese de Mestrado].

OLIVEIRA, MP., VIEIRA, I. and OLIVEIRA, MHR., 1971. Sobre Bradybaena similaris (Férussac, 1821) (Gastropodo, Pulmonata, Stylommatophora, Fruticicolidae) Copula y funcionamiento del oviducto durante el periodo de fecundacion 
y formacion del huevo. Com. Soc. Malac. Urug., vol. 3, p. $155-161$.

PINHEIRO, J. andAMATO, SB., 1994. Eurytrema coelomaticum (Digenea, Dicrocoelidae): the effect of infection on carbohydrate content of its intermediate snail host, Bradybaena similaris (Férussac, 1821) (Mollusca, Gastrpopda). Mem. Inst. Oswaldo Cruz., vol. 89, no. 3, p. 407-410.

PINHEIRO, J. and GOMES, EM., 1994. A method for glycogen determination in mollusc. Arq. Biol. Tecnol., vol. 37, no. 3, p. 569-576.

PINHEIRO, J., 1996. Influence of starvation on the glycogen and galactogen content in the snail Bradybaena similaris (Férussac, 1821) (Mollusca, Gastropodo). Arq. Biol. Tecnol., vol. 39 , no. 2, p. 349-357.

SANTOS, O., 1994. Presencia de Bradybaena similaris (Férussac, 1821) em el Uruguai. Com. Soc. Malac. Urug., vol. 7, p. 376-378.

SUMNER, JB., 1924. A method for colorimetric determination for phosporus. Science, vol. 100, no. 2601, p. 413-414.
THIENGO, SARC., 1995. Estudo da helmintofauna dos moluscos em áreas de ocorrência de angiostrongilose no Brasil. (Tese de Doutorado) - UFRRJ. Seropédica, RJ, Brasil, 91 p.

THOMÉ, WJ., SILVA, AV. and SANTOS, DD., 1996. Manual de aulas práticas de zoologia: estudo morfo-anatômico de um Molusco Sigmuretra. Cadernos EDIPUCRS 12, Série Zoologia 2. Porto Alegre: Pontifícia Universidade Católica do Rio Gande do Sul.

VAN ELK., R. and JOOSSE, J., 1981. The UDP-galctose 4-epimerase of the albumen gland of Lymneae stagnalis and the effects of photoperiod, starvation and trematodes infection on its activity. Comp. Biochem. Physiol., vol. 70B, no. 1, p. 45-52.

VILELA, GG., BACILA, M. and TASTALDI, H., 1973. Técnicas e experimentos de Bioquímica. Rio de Janeiro, R.J., Brasil: Editora Guanabara Koogan. 552 p.

VINCENT, CA., DERAY, A., ENEE, J., CLERC, M., JUGAND, MH. and BOLZONI, D., 1982. Nombre d'oeufs par ponte, durée d'incubation et croissance en labaoratoire de Helix pomatia $\mathrm{L}$. (Gastropoda, Pulmonata). Haliotis, vol. 12, p. 13-20. 